\title{
Empowering Leadership and Work Engagement: The Role of Psychological Empowerment as a Mediator
}

\section{Rizqi Zulfa Qatrunnada ${ }^{\mathrm{a}}$ and Endang Parahyanti ${ }^{\mathrm{b}}$}

${ }^{a}$ Faculty of Psychology, Universitas Indonesia, Depok, Indonesia; ${ }^{b}$ Department of Industrial and Organizational Psychology, Faculty of Psychology, Universitas Indonesia, Depok, Indonesia

*Corresponding author:

Endang Parahyanti

Department of Industrial and Organizational Psychology

Faculty of Psychology, Universitas Indonesia

Depok, Jawa Barat, Indonesia

Email address: parahyanti@gmail.com 


\title{
Empowering Leadership and Work Engagement: The Role of Psychological Empowerment as a Mediator
}

\begin{abstract}
Millennials' domination of the workplace has resulted in increasing attention to the issue of engagement. Leaders need to enhance their understanding of leadership empowerment behavior as a means to increase employee engagement. Psychological empowerment encompasses a set of conditions necessary for intrinsic motivation and has been proposed as a mediator in the relationship between empowerment leadership and work engagement. This study explores the mediating role of psychological empowerment in relations between empowering leadership and the work engagement of millennial employees in Indonesia. A cross-sectional convenience survey design was used to collect data at a single time with an online and offline survey. Participants $(n=140)$ were Indonesian millennial employees from various organizations. The Empowering Leadership Questionnaire (ELQ), Measuring Empowerment Questionnaire (MEQ), and Work Engagement short version (UWES-9) were administered, and the mediation model Hayes and PROCESS Macro were used to investigate the hypothesis of the mediation role of psychological empowerment in relations between the variables. The results confirmed that psychological empowerment mediates the relationship between empowering leadership and work engagement. This research was conducted as an extension of previous research that further explores the role of psychological empowerment as a mediator in relations between empowering leadership and work engagement among millennial employees, particularly in Indonesia. This research has practical implications for how to engage millennial workers with empowering leadership styles, and it can inform the implementation of discussions and training programs promoting empowerment and developmental approaches in employment contexts.
\end{abstract}

Keywords: empowering leadership, psychological empowerment, work engagement

\section{Introduction}

The emerging phenomenon of Millennials' domination of the world marketplace has received special attention from companies and researchers. In employment contexts, many studies have defined and explored differences between Millennials and earlier generations such as Baby Boomers and Gen-X (Hannus, 2013; Pyöriä, Ojala, Saari, \& Järvinen, 2017; Ursachi, 2013). Born after 1980, Millennials differ from previous generations in that they are better educated, more technologically-savvy, have higher levels of self-esteem, expect more support and provide more feedback, and are more actively seeking self-development, achievement, and recognition (Pyöriä et al., 2017; Ursachi, 2013). However, in the workplace, Millennials are also known to have lower work engagement and tend to be less loyal to their organizations. Parsons found the turnover trend in Millennials to be significantly higher than that of the oldest generation. Therefore, the issue of Millennials' work engagement is important to examine. 
In Indonesia, a survey conducted by the Indonesian Central Bureau of Statistics in 2018 showed that Millennials comprise $36.28 \%$ (48.6 million) of the total national workforce of 133.94 million people, compared with 57.2 million (42.72\%) Gen-Xers (1965-1980), 21.2 million (15.86\%) Baby Boomers (1945-1964), and 6.9 million (5.14\%) unemployed. With the retirement of Baby Boomers and the promotions of Gen-Xers to higher positions, Millennials have increasingly dominated the labor force. A Dale Carnegie Indonesia study of employee engagement among Millennials in 2016, which involved 1,200 participants who were employees in the six largest cities of Indonesia-Jakarta, Surabaya, Bandung, Makassar, Balikpapan, and Medan - found that 9\% Millennials were disengaged, 66\% of them were partially-engaged, and only $25 \%$ were fully-engaged. Furthermore, although $64 \%$ of the respondents reported remaining with their companies for at least a year, $60 \%$ of them planned to resign if they felt disengaged with the organization. This can pose grave challenges for companies because Millennials can easily become disengaged if the company does not anticipate their needs. Therefore, companies require different strategies to attract, motivate and retain Millennials.

According to Saragih (2016), at least one among eight examined predictor variables - namely compensation, benefit, promotion opportunities, supervision, work flexibility, the task, work location, and relationship with colleagues - had a significant correlation with organizational commitment among Indonesian millennial workers. Another study conducted by Asghar (2014) found that $88 \%$ of Millennials prefer workplaces with collaborative rather than competitive work cultures, $74 \%$ want a flexible work schedule, $88 \%$ desire work-life balance, and $79 \%$ want supportive leaders who can be serve as coaches or mentors.

The role of leaders is an important factor in company outcomes, particularly in terms of handling Millennials (Brown et al., 2009; Hannus, 2016; Meier, Austin, \& Crocker, 2010). Companies need to increase organizational flexibility and effectiveness by replacing traditional hierarchical leadership models to empower team members by emphasizing semi-autonomy and selfmanagement (Arnold \& Drasgow, 2000). Empowering leadership focuses on developing employee strengths (Nel, Stander, \& Latif, 2015); it is a leadership model that empowers group members to work independently and trains group members to develop self-management or selfleadership skills (Ahmad \& Gao, 2018; Zhang \& Bartol, 2010).

Empowering leadership encourages employees to determine their own ways to perform. According to Arnold and Drasgow (2000), the fundamental difference between traditional leader behavior and that of empowering leaders is rooted in a shift in the source of control from the leader to the team members, which aims to help team members function and perform as a self-managed business unit. They proposed five dimensions that are important for empowering leadership: (1) leading by example, which refers to behavior that shows the leader's commitment to his work and team members; (2) coaching, which denotes educating and helping team members to become self-reliant; (3) participative decision making, which refers to providing opportunities for team members to help make decisions; (4) informing, which entails leaders disseminating the organization's vision, mission, goals, and other important information; and 
(5) showing concern/interacting with employees by demonstrating behaviors that emphasize attention to team members' well-being and interfacing with the whole team.

Menon (2001) suggested that in order to better understand the empowerment process, it is necessary to study it from the perspective of the individual employee, which means understanding that to promote such behavior, employees need to feel psychologically empowered. Psychological empowerment is described by Spreitzer (1995), as an experienced psychological state or set of cognitions manifested in four dimensions, namely meaningfulness, competence, self-determination, and impact. Meaningfulness refers to an individual subjective assessment of work and reflects an employee's personal connection and feeling that their work is essential and they care about what they are doing. Competence reflects a belief that the individual has the skills and abilities needed to achieve their goals (self-efficacy). Selfdetermination denotes a sense of control, autonomy and freedom of choice to properly fulfill and perform tasks. Finally, impact indicates an individual's confidence in their ability to contribute to their work and work environment.

Based on the above, empowering leadership should have significant effects on an employee's psychological empowerment (Meng, Zou, He, \& Luo, 2012). This idea is supported by research conducted by Zhang and Bartol (2010) who found empowering leadership to be a predictor of psychological empowerment.

Empowering leadership has also been widely examined as a variable that impacts work engagement among millennial workers (De Klerk \& Stander, 2014; Dewettinck \& Van Ameijde, 2005; Mendes \& Stander, 2011; Stander \& Rothmann, 2010). Work engagement can be defined as "a positive, fulfilling, work-related state of mind that is characterized by vigor, dedication, and absorption" (Schaufeli \& Bakker, 2002). Vigor is characterized by "high levels of energy and mental resilience while working, the willingness to invest effort in one's work, and persistence also in the face of difficulties," whereas dedication refers to "being strongly involved in one's work and experiencing a sense of significance, enthusiasm, inspiration, pride, and challenge," and absorption can be described as "being fully concentrated and happily engrossed in one's work, whereby time passes quickly and one has difficulties with detaching oneself" (Schaufeli, Bakker, \& Salanova 2006).

Leaders with all of these attributes are seen as supportive leaders who are able to guide, provide examples, treat employees fairly, and provide opportunities for subordinates to make decisions in their work independently. This in turn makes subordinates feel more competent, like they have autonomy, and gives them confidence in their ability to contribute to work and the organization, thus promoting a meaningful relationship (personal connection) with their work. Employees who imagine empowerment in a positive way tend to experience greater psychological empowerment when the leader gives them autonomy in their work (Zhang \& Bartol, 2010). In turn, employees who feel psychologically empowered tend to be more engaged to their work and loyal to their organization. 
Based on the above, for the purposes of this study, psychological empowerment was hypothesized as a mediator of the effect of empowering leadership on work engagement. The hypothesis model is illustrated in Fig. 1.

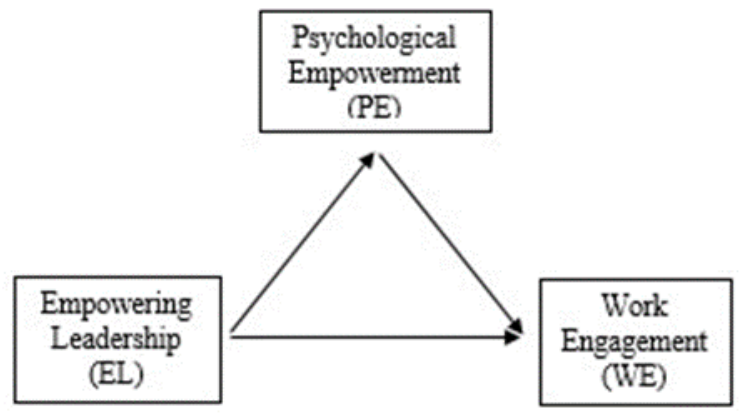

Fig. 1. The mediation model of empowering leadership, psychological empowerment, and work-engagement

This study aimed to examine the hypothesized role of psychological empowerment as a mediator on the relationship between empowering leadership and work engagement among Millennials in Indonesia. This research is expected to contribute to the literature related to empowerment and can inform companies' efforts in implementing empowering leadership to improve psychological empowerment and work engagement among their millennial employees.

\section{Methods}

\section{Research Design and Procedure}

A quantitative research methodology was used for this study, whereby researchers adopted a cross-sectional convenience survey design to collect data at a single time based on online and offline survey. The online survey was administered by sharing a link to social media such as via Email, WhatsApp, and Line Messenger, whereby data from the offline survey was collected by distributing the questionnaires directly to the participants during normal working hours. Participation in this research project was voluntary. Information was provided to the respondents to outline the purposes of the study and researchers secured their informed consent to participate in study. Researchers assured participants of the confidentiality and anonymity of their responses.

\section{Participants}

The study participants were 140 Indonesian Millennials working in various situations, namely the private sector (40\%), state-owned enterprises (29\%), and the public sector (28\%). The study sample comprised 55 males (39.29\%) males and 85 females $(60.71 \%)$ females between the ages of 20 and $35(\mathrm{M}=27.3, \mathrm{SD}=3.6)$. A total of $7.86 \%$ of the respondents had completed senior high school, 5.71\% had a diploma, 63.86\% had a bachelor's degree, and $23.57 \%$ had earned a master's degree. The majority of the respondents were permanent employees $(64 \%)$, whereas others were contract workers $(36 \%)$, and their work tenures comprised $1-2$ years $(30 \%)$, and more than 2 years $(70 \%)$. 


\section{Measurement Instruments}

Empowering Leadership. The Empowering Leadership Questionnaire (ELQ) consists of 18 items. The five dimensions of empowering leadership were measured using the scales proposed by Xue, Bradley, and Liang (2011) and adapted by Hardigaloeh $(2014 ; \alpha=.95))$. All items were evaluated by a six-point Likert scale ranging from 1 = "strongly disagree" to $6=$ "strongly agree." An example item is "my team leader sets high standards for performance by his/her own behavior.

Psychological Empowerment. The measure of an individual's perspective of psychological empowerment was the Measuring Empowerment Questionnaire (MEQ) by Spreitzer (1995), which was adapted by Sari (2014). The instrument consists of 12 items scored on a six-point Likert scale ranging from $1=$ "strongly disagree" to $6=$ "strongly agree." An example statement is "the work I do is very important to me." The Cronbach's alpha coefficient for the adapted MEQ scale was.96 (Sari, 2014).

Work Engagement. The Utrecht Work Engagement Scale short version comprises (UWES-9) nine items scored on a seven-point frequency scale ranging from $1=$ "almost never or never" to 7 = "always or almost always." This scale was adapted by Novena (2013) and the Cronbach's alpha coefficient was.87. An example item is "at my job, I feel strong and vigorous."

\section{Data Analysis}

The researchers followed Hayes' (2013) procedure for assessing the mediating role of psychological empowerment in the relationship between the variables. All of the data analysis was conducted using IBM SPSS Statistics version 24 and PROCESS Macro for SPSS version 2.16.3. To evaluate the mediation model, total, direct, and indirect effects were estimated on the basis of 10.000 bootstrapped samples and a confidence interval of $95 \%$.

\section{Results}

\section{Descriptive Statistics and Correlations}

The descriptive statistics, reliability coefficients, and correlations of the scales $(\mathrm{N}=140)$ are illustrated in Table 1. The data showed that there is a significant correlation between empowering leadership, psychological empowerment, and work engagement. Each of the Cronbach alpha's coefficients is above.91, thus demonstrating that the measurements have good internal consistency (Kaplan, Robert, \& Saccuzzo, 2013).

Table I. Means, standard deviations, and correlations for the study variables

\begin{tabular}{|l|l|l|l|l|l|}
\hline & M & SD & $\mathbf{1}$ & $\mathbf{2}$ & $\mathbf{3}$ \\
\hline $\mathbf{1}$ & 40.46 & 9.27 & $(.92)$ & & \\
\hline $\mathbf{2}$ & 82.11 & 17.17 & $.474^{* *}$ & $(.96)$ & \\
\hline $\mathbf{3}$ & 57.06 & 8.75 & $.629^{* *}$ & $.412^{* *}$ & $(.91)$ \\
\hline
\end{tabular}

${ }^{1}$ Work Engagement, ${ }^{2 .}$ Empowering Leadership, ${ }^{3 .}$ Psychological Empowerment $* *$ Correlation is significant at the 0.01 level (2-tailed). 


\section{Mediation Analysis}

The proposed mediator (see Fig. 2), i.e., psychological empowerment, was regressed on empowering leadership to produce $a$, and work engagement was regressed on both psychological empowerment and empowering leadership, which yielded $b$ and $c$ ', respectively.

The results shown in Table II demonstrate that empowering leadership was a significant predictor of psychological empowerment $(\beta=.21, S E=0.04, \mathrm{p}<.001)$; this variable explained 17 percent of the variance in psychological empowerment $\left(R^{2}=.1701\right)$. The results also suggested that psychological empowerment significantly predicted work engagement $(\beta=.55$, $S E=0.07 \mathrm{p}<.001)$. Additionally, empowering leadership was a significant predictor of work engagement after controlling the psychological empowerment mediator $(\beta=.14, S E=0.04, \mathrm{p}$ $=.0003)$. Empowering leadership explained $45.1 \%$ of the variance in work engagement $\left(R^{2}=.4515\right)$.

Furthermore, multiplying $a$ and $b$ yielded an indirect effect, which was estimated as $a b=$ $0.21(0.55)=0.116$ and provided in the PROCESS output. This result demonstrates that the more a leader demonstrated empowerment behavior, the more the employee felt psychologically empowered ( $a$ is positive), which in turn was positively related to their work engagement ( $b$ is positive). The result of the indirect effect indicates that psychological empowerment mediated the relationship between empowering leadership and work engagement among the participants ( $\beta=.116, S E=.0358,95 \% \mathrm{CI}=.0567, .1993)$. The indirect effect is positively shown by the fact that confidence interval does not reach zero and is also above zero (Hayes, 2013). Therefore, the hypothesis was supported.

The direct effect of empowering leadership, $c^{\prime}=0.14$, is the estimated difference in work engagement between two employees experiencing the same level of psychological empowerment who differ by one unit in their reported empowering leadership. The positive coefficient denotes that those experiencing relatively higher empowering leadership are estimated to also be higher in their work engagement $(\beta=.1393, S E=.0375)$. The direct effect is statistically different from zero, $t(137)=3.7166, p=0.0003$, with a $95 \%$ confidence interval from 0.0652 to 0.2135 .

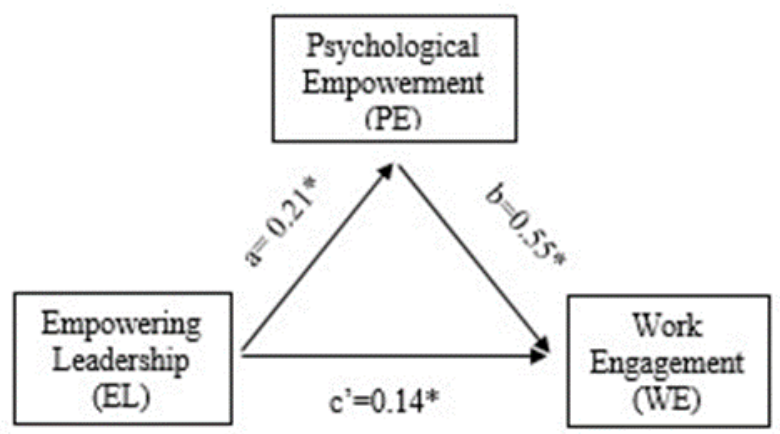

Fig. 2. Statistical model of Work engagement as a mediation in empowering leadership and work-engagement relationship 
Table II. Model Coefficients for the empowering leadership study

\begin{tabular}{|c|c|c|c|c|c|c|c|c|}
\hline \multirow{3}{*}{ Antecedent } & \multicolumn{8}{|c|}{ Consequent } \\
\hline & \multicolumn{4}{|c|}{$P E$} & & \multicolumn{3}{|l|}{ WE } \\
\hline & & Coeff & $S E$ & $p$ & & Coeff & $S E$ & $p$ \\
\hline $\mathbf{E L}$ & $\mathrm{a}$ & 0.21 & 0.04 & $<.001$ & $\mathrm{c}^{\prime}$ & 0.14 & 0.04 & 0.0003 \\
\hline PE & & & & & $\mathrm{b}$ & 0.55 & 0.07 & $<.001$ \\
\hline constant & $i_{1}$ & 39.79 & 3.32 & $<.001$ & $\mathrm{i}_{2}$ & 0.67 & 4.09 & .53 \\
\hline $\mathbf{R}^{2}$ & \multicolumn{4}{|c|}{$\mathrm{R}^{2}=0.1701$} & \multicolumn{4}{|c|}{$\mathrm{R}^{2}=0.4515$} \\
\hline F statistic & \multicolumn{4}{|c|}{$\mathrm{F}(1,138)=28.2798, \mathrm{p}<.001$} & \multicolumn{4}{|c|}{$\mathrm{F}(2,137)=56.387, \mathrm{p}<.001$} \\
\hline
\end{tabular}

Thus, the total effect of empowering leadership on work engagement is obtained by totaling the direct and indirect effects (Hayes, 2013): $\mathrm{c}=c^{\prime}+a b=0.14+0.116=0.256$. The results show that two people who differ by one unit in empowering leadership are estimated to differ by 0.25 units in their reported work engagement. The positive sign denotes that the leader who develops empowerment behavior obtains higher employee engagement in their work. However, this effect did not include zeros, $\beta=.25, S E=.0405, t(138)=6.3207, p<0.001$, or between 0.1757 and 0.3357 with a $95 \%$ confidence interval.

\section{Discussion and Conclusion}

The present study examined empowerment support as a predictor of work engagement among the millennial workers in Indonesia. The results support findings from previous studies by demonstrating that empowering leadership and psychological empowerment are positively linked to work engagement (De Klerk \& Stander, 2014; Dewettinck \& Van Ameijde, 2005; Nel, Stander, \& Latif, 2015). This research result also lends support to the findings of De Klerk and Stander (2014) regarding the effect of the mediating role of psychological empowerment in the relationship between empowering leadership and work engagement. These findings indicate that the greater the leader's empowerment behavior of the leader, the more the employee feels empowered psychologically, which in turn leads the employee to feel more engaged in their work.

In other words, the results showed that employees who have an empowering leader will feel more competent and in control (Ahmad \& Gao, 2018), as they are provided the autonomy to encourage self-regulation and enhance their self-confidence to perform well at their work (Meng et al., 2012). Psychologically, such employees will perceive themselves as being empowered and experience meaning in their work (Ching, 2012). For Millennials, performing meaningful work and working with committed co-workers with shared values are important personal goals (Pyöriä et al., 2017). When an individual feel that what they do is meaningful and give an impact on the organization, they will be more loyal to and engaged in their job (Bhatnagar, 2012; De Klerk \& Stander, 2014; May, Gilson, \& Harter, 2004). Empowering leadership has also been considered as a motivational resource that enhances the employee's confidence in their own abilities (Chen, 2016; Ugwu, Onyishi, \& Rodríguez-Sánchez, 2014). Empowered employees with high self-efficacy and competence will exert more energy and dedication toward performing their tasks better (Macsinga, Sulea, Sârbescu, Fischmann, \& Dumitru, 2015; Stander 
\& Rothmann, 2010), and they have been observed to be highly engaged and more committed to their work (Avolio, Zhu, Koh, \& Bhatia, 2004; Chen, 2016).

The theoretical implications of these findings bring a valuable contribution to existing working engagement literature, particularly that concerning Indonesian Millennials in the workplace. This research also provides a theoretical contribution to research concerning another type of leadership behavior for empowered teams. Among the study's practical implications is that organizations need to evaluate their leadership behavior and encourage leaders to apply an empowered-based approach, including behaviors such as working harder than team members, educating and helping team members to be self-reliant, encouraging the team to give a high performance by showing trust in their work competence, providing opportunities for participating in decision making, sharing and explaining new information and buffering bureaucracy, as well as showing concern and interacting with the team as a whole. Developing such empowering leadership behaviors, will enhance employees' psychological empowerment, which in turn will increase their work engagement and promote greater retention of talent. In addition, it is also recommended to engage in leadership style discussions and implement training programs that emphasize empowerment and developmental approaches.

This research was conducted to extend previous studies that explored the mediating role of psychological empowerment on the effects of leadership empowerment and outcome variables in Millennials employment settings, particularly in Indonesia. Even so, the population will be better represented if future research increases the number of participants. In addition, it is recommended to investigate the effects of empowerment and work engagement on other work outcomes such as affective organizational commitment, organizational citizenship behavior and turnover intention to further explore its impacts on millennial workers, particularly in Indonesia.

\section{References}

Ahmad, I., \& Gao, Y. (2018). Ethical leadership and work engagement: The roles of psychological empowerment and power distance orientation. Management Decision, 56(9), 1991-2005.

Arnold, J., \& Drasgow, F. (2000). The Empowering Leadership Questionnaire: The Construction and Validation of New Scale for Measuring Leader Behaviors. Journal of Organizational Behavior, 21, 249-269

Asghar, R. (2014). Study: millennials are the true entrepreneur generation. [Online]. Retrieved from https://www.forbes.com/sites/robasghar/2014/11/11/study-millennials-are-the-true-entrepreneurgeneration/\#2c19698c73dc.

Avolio, B. J., Zhu, W., Koh, W., \& Bhatia, P. (2004). Transformational leadership and organizational commitment: Mediating role of psychological empowerment and moderating role of structural distance. Journal of Organizational Behavior: The International Journal of Industrial, Occupational and Organizational Psychology and Behavior, 25(8), 951-968.

Badan pusat statistik (2018). In Tenaga Kerja - Penduduk Berumur 15 Tahun Ke Atas Menurut Golongan Umur dan Jenis Kegiatan. Indonesia.

Bhatnagar, J. (2012). Management of innovation: role of psychological empowerment, work engagement and turnover intention in the Indian context. The International Journal of Human Resource Management, 23(5), 928-951.

Brown, S., Carter, B., Collins, M., Gallerson, C., Giffin, G., Greer, J., ... \& Richardson, K. (2009). Generation Y in the Workplace (Research). Texas A\&M University, Texas.

Chen, I. S. (2016). Examining the linkage between creative self-efficacy and work engagement: the moderating role of openness to experience. Baltic Journal of Management, 11(4), 516-534. 
Ching, Y. (2012). Empowering leadership behaviors and work outcomes: mediating role of psychological empowerment and moderating role of need for achievement (Unpublished Bachelor thesis). Hong Kong Baptist University, Hong kong.

De Klerk, S., \& Stander, M. W. (2014). Leadership empowerment behaviour, work engagement and turnover intention: the role of psychological empowerment. Journal of Positive Management, 5(3), 28-45. doi: 10.12775/JPM.2014.018.

Dewettinck, K., \& Van Ameijde, M. (2011). Linking leadership empowerment behaviour to employee attitudes and behavioural intentions. Personnel Review, 40(3), 284-305. doi: 10.1108/00483481111118621.

Hannus, S. (2016). Traits of the millennial generation: Motivation and leadership (Master thesis). AALTO University School of Business, Finland.

Hardigaloeh, A. R. (2014). The improvement of empowering leadership role towards knowledge sharing through encouraging knowledge sharing at work training intervention for PT ABC employee (Master thesis). Universitas Indonesia, Depok.

Hayes, A. F. (2013). Introduction to Mediation, Moderation, and Conditional Process Analysis: a Regressionbased approach. The United States of America: The Guilford Press.

Kaplan, R. M., \& Saccuzzo, D. P. (2017). Psychological testing: Principles, applications, and issues (8 $8^{\text {th }}$ ed.). Belmont, CA: Wadsworth

Macsinga, I., Sulea, C., Sârbescu, P., Fischmann, G., \& Dumitru, C. (2015). Engaged, committed and helpful employees: The role of psychological empowerment. The Journal of psychology, 149(3), 263-276.

May, D. R., Gilson, R. L., \& Harter, L. M. (2004). The psychological condition of meaningfulness, safety and availability and the engagement of the human spirit at work. Journal of Occupational and Organizational Psychology, 77(1), 11-37. doi: 10.1348/096317904322915892.

Meier, J., \& Crocker, M. (2010). Generation Y in the workforce: Managerial challenges. The Journal of Human Resource and Adult Learning, 6(1), 68-79.

Mendes, F., \& Stander, M. W. (2011). Positive organisation: the role of leader behaviour in work engagement and retention. SA Journal of Industrial Psychology, 37(1). doi: 10.4102/sajip.v37i1.900.

Meng, Y., Zou, L., He, J., \& Luo, C. (2012). Nankai Business Review International Article information.

Menon, S. T. (2001). Employee empowerment: an integrative psychological approach. Applied Psychology, 50(1), 153-180. doi: 10.1111/1464-0597.00052.

Nel, T., Stander, M. W., \& Latif, J. (2015). Investigating positive leadership, psychological empowerment, work engagement and satisfaction with life in a chemical industry. SA Journal of Industrial Psychology, 41(1), 1-14. doi: 10.4102/sajip.v41i1.1243.

Novena, M. M. N. (2013). Intervention program to improve work engagement in XYZ company based on variable procedural justice, psychological hardiness and commitment to change (Master thesis). Universitas Indonesia, Depok.

Pyöriä, P., Ojala, S., Saari, T., \& Järvinen, K. M. (2017). The millennial generation: a new breed of labour? Sage Open, 7(1), 1-14

Saragih, E. H., Widodo, A., \& Prasetyo, B. (2016). Big city millenial workers in Indonesia and factors affecting their commitment to the organisation. Pertanika Journal of Social Science and Humanities, 24, 47-58.

Sari, N. R. (2014). The influence of structural and psychological empowerment toward turnover intentions with job satisfaction as mediating variable of workers among MM UNJ student (Master thesis). Universitas Indonesia, Depok.

Schaufeli, W. B., Bakker, A. B., \& Salanova, M. (2006). The measurement of short questionnaire: A cross-national study. Educational and Psychological Measurement, 66(4), 701-716. doi: 10.1177/0013164405282471.

Schaufeli, W. B., \& Bakker, A. B. (2004). Job demands, job resources, and their relationship with burnout and engagement: A multi-sample study. Journal of Organizational Behavior: The International Journal of Industrial, Occupational and Organizational Psychology and Behavior, 25(3), 293-315.

Spreitzer, G. M. (1995). Psychological empowerment in the workplace: dimensions, measurement, and validation. Academy of Management Journal, 38(5).

Stander, M. W., \& Rothmann, S. (2010). Psychological empowerment, job insecurity and employee engagement. SA Journal of Industrial Psychology, 36(1), 1-8. doi: 10.4102/sajip.v36i1.849. 
Ugwu, F. O., Onyishi, I. E., \& Rodríguez-Sánchez, A. M. (2014). Linking organizational trust with employee engagement: the role of psychological empowerment. Personnel Review, 43(3), 377-400. doi: 10.1108/PR-11-2012-0198.

Ursachi, D. (2013). Leadership-profile, motivation-and workplace attitude for the Millennial generation.

Xue, Y., Bradley, J., \& Liang, H. (2011). Team climate, empowering leadership, and knowledge sharing. Journal of Knowledge Management, 15(2), 299-312. doi: 10.1108/13673271111119709.

Zhang, X., \& Bartol, K. M. (2010). Linking empowering leadership and employee creativity: the influence of psychological empowerment, intrinsic motivation, and creative process engagement. Academy of Management Journal, 53(1), 107-128. doi: 10.5465/amj.2010.48037118. 